\title{
PENGARUH PENAMBAHAN CARBOXY METHYLCELLULOSE DAN WAKTU PEMASAKAN TERHADAP MUTU SELAI NANAS
}

\author{
(The Effect of Addition of Carboxy Methylcellulose and Cooking Time on the \\ Quality of Pineapple Jam) \\ Naomi Uli Arta Siagian', Abdul Rahim ${ }^{2}$, Baharuddin ${ }^{1}$, If'all ${ }^{1}$ \\ 1) Program Studi Teknologi Hasil Pertanian Universitas Alkhairaat Palu \\ Jl. Diponegoro No. 39 Palu Sulawesi Tengah 94221 \\ ${ }^{2)}$ Program Studi Agrotecnologi, Fakultas Pertanian, Universitas Tadulako Palu \\ Jln. Soekarno Hatta Km. 9 Palu Sulawesi Tengah Indonesia 94118 \\ Corresponding author : ifall@unisapalu.ac.id
}

Article Submitted : 07-02-2019

Article Accepted : 01-04-2019

\begin{abstract}
Pineapple Jam Quality Quality is determined by CMC concentration factors and cooking time. This study aims to study the effect of the addition of CMC and the length of cooking on the quality of pineapple jam so that it can be accepted by consumers. This research was conducted at the Laboratory of Processing, Faculty of Agriculture, Alkhairaat University Palu and Agro-Industry Laboratory, Faculty of Agriculture, University of Tadulako Palu. This research was conducted using factorial experiments arranged in a Randomized Block Design with three replications. The first factor of CMC concentration consisted of treatments $\mathrm{C} 1=0.5 \%, \mathrm{C} 2=1.0 \%$, and $\mathrm{C} 3=1.5 \%$. The second factor is the length of cooking, namely drying $\mathrm{T} 1=20$ minutes, $\mathrm{T} 2=25$ minutes and $\mathrm{T}=30$ minutes. The data obtained were analyzed by variance, followed by the BNJ test at the $0.05 \%$ level with the parameters of the test of amendment, moisture content, ash content, dietary fiber content, vitamin $\mathrm{C}$, total acid content, and organoleptic test. The results showed that the best combination was found in $0.5 \% \mathrm{CMC}$ concentration with 20 minutes cooking time. The treatment characteristics of $0.5 \% \mathrm{CMC}$ concentrations with a cooking duration of 20 minutes resulted in better pineapple jams including water content $(46.60 \%)$, ash content $(0.86 \%)$, vitamin C $(14.30 \%)$, and organoleptic levels the best for the aroma of pineapple jam on the treatment of $0.5 \% \mathrm{CMC}$ concentration with a cooking duration of 20 minutes obtained the highest panelist assessment score of (4.72) with the "very like" hedonic scale.
\end{abstract}

Keyword : $\mathrm{cmc}$, cooking time, pineapple jam

\section{PENDAHULUAN}

Tanaman nanas (Ananas comosus (L) Merr] adalah tanaman buah yang sudah dikenal di Indonesia. Permintaan pasar dalam negeri terhadap buah nanas cenderung terus meningkat sejalan dengan pertumbuhan jumlah penduduk, makin baiknya pendapatan masyarakat, makin tingginya kesadaran penduduk akan nilai gizi dari buah-buahan dan 
makin bertambahnya permintaan bahan baku industri pengolahan buah-buahan.

Buah nanas selain dikonsumsi segar juga dapat diolah menjadi berbagai produk makanan dan minuman, seperti dibuat jam (selai), sari buah, dodol, manisan, buah dalam kaleng, kripik, sirup dan lain-lain.Buah nanas merupakan buah klimaterik yang mengandung vitamin $\mathrm{C}$ dan vitamin A. Kedua vitamin tersebut mempunyai aktivitas sebagai antioksidan yang mampu menghentikan reaksi berantai pembentukan radikal bebas dalam tubuh manusia yang diyakini sebagai pemicu berbagai penyakit (Posman, 2008).

Pada saat terjadi panen raya, jumlah produksi buah nanas sangat melimpah namun tidak sebanding dengan tingkat konsumsinya sehingga harga jual dipasar sangat murah. Untuk mencegah tidak termanfaatkannya buah nanas pada saat jumlahnya sangat melimpah perlu dilakukan usaha untuk memperpanjang umur simpan, meningkatkan nilai ekonomis dan penganekaragaman produk sehingga dapat diterima oleh konsumen.Buah nanas selain dapat dikonsumsi dalam bentuk segar, dapat pula diolah lebihlanjut menjadi berbagai bentuk olahan antara lain:sari buah, manisan, keripik, nata de pina,selai dan lain sebagainya (Indriyani, 2008).

Selai merupakan jenis makanan olahan yang berasal dari sari buah atau buah-buahan yang sudah dihancurkan, ditambah gula dan dimasak sampai mengental. Selai tidakdikonsumsi langsung, melainkan digunakan sebagai bahan pelengkap pada roti tawar atau sebagai bahan pengisi pada roti manis, kue nastar atau sebagai pemanis pada minuman seperti yogurt dan es krim (Syahrumsyah $d k k, 2010$ ).

Dalam pembuatan selai dipengaruhi beberapa faktor, antara lain adalah pemanasan pada waktu pemasakan, pengadukan, jumlah gula yang digunakan, serta keseimbangan gula, pektin, carboxy methyl cellulose dan asam. (BPTP, 2007). Untuk mendapatkan selai yang baik dan bersifat fungsional maka biasa ditambahkan senyawa pengemulsi misalnya CMC, agar-agar dan sebagainya. Menurut Syahrumsyah $d k k$., (2010) bahwa penambahan CMC dan tingkat kematangan buah nanas berpengaruh nyata terhadap warna, rasa, aroma dan kekentalan selai nanas, tetapi tidak pengaruh terhadap kadar vitamin $\mathrm{C}$, kadar gula dan $\mathrm{pH}$. Darisemua interaksi perlakuan panelis menyukaiselai nanas yang dibuat dari perlakuanpenambahan $\mathrm{CMC} 1,5 \mathrm{~g}$ dan buah nanas $50 \%$ hijau dan $50 \%$ kuning, dengan kadar vitamin C 15,4 mg per 100 g, kadar gula $61,16 \%$, pH 4,50, warna 5,40, rasa 5,47, aroma 5,03 dan kekentalan 5,17.

\section{METODE PENELITIAN}

\section{Alat dan Bahan}

Alat yang digunakanpenelitian yaitu: pisau, talenan, blender, saringan, loyang, timbangan, sendok/pengaduk kayu, label, gelas ukur, panci, kompor gas, pipet tetes dan alat tulis menulis. Alat yang digunakan analisis: tabung reaksi dan rak tabung, cawan, oven desikator, timbangan analitik, labu takar, sentrifuge, erlenmeyer, kertas saring, spatula, stoples. Bahan yang digunakan untuk penelitian antara lain: Buah nanas daerah Doda, gula pasir $200 \mathrm{~g}$, asam cuka $1 \mathrm{ml}$, dan CMC $(0,5 \%, 1 \%$, dan $1,5 \%)$. Bahan yang digunakan untuk analisis: Iodin, aquades, alkohol 95\%, larutan $\mathrm{KOH}$, indikator phenolphthalein (PP), bromothymol-blue, larutan $\mathrm{H}_{2} \mathrm{SO}_{4}$, larutan $\mathrm{N}_{\mathrm{a}} \mathrm{OH}$, larutan $\mathrm{K}_{2} \mathrm{SO}_{4}$.

\section{Metode}

Penelitian ini dilaksanakan dengan menggunakan Rancangan Acak Kelompok (RAK) dengan 2 faktor, faktor pertama adalah melakukan konsentrasi penambahan CMC sebagai bahan hidrokoloid dalam Selai Nanas (C) meliputi: $\mathrm{C}_{1}=0,5 \% ; \mathrm{C}_{2}=1,0 \%$ dan $\mathrm{C}_{3}=$ $1,5 \%$, Sedangkan faktor kedua adalah waktu pemasakan $(\mathrm{T})$ meliputi $: \mathrm{T}_{1}=20$ menit; $\mathrm{T}_{2}=$ 
25 menit dan $T_{3}=30$ menit Sehingga terdapat sembilan kombinasi perlakuan dan setiap kombinasi perlakuan diulang sebanyak tiga kali hingga menjadi 27 unit percobaan.

\section{Pelaksanaan}

1. Buah nanas dipilih yang matang, bebas dari hama dan penyakit serta kerusakan mekanis lainnya. Kemudian buah nanas dikupas kulit dan matanya dengan menggunakan pisau dapur.

2. Daging nanas dicuci dengan air bersih yang mengalir untuk menghilangkan kotoran pada daging buah.

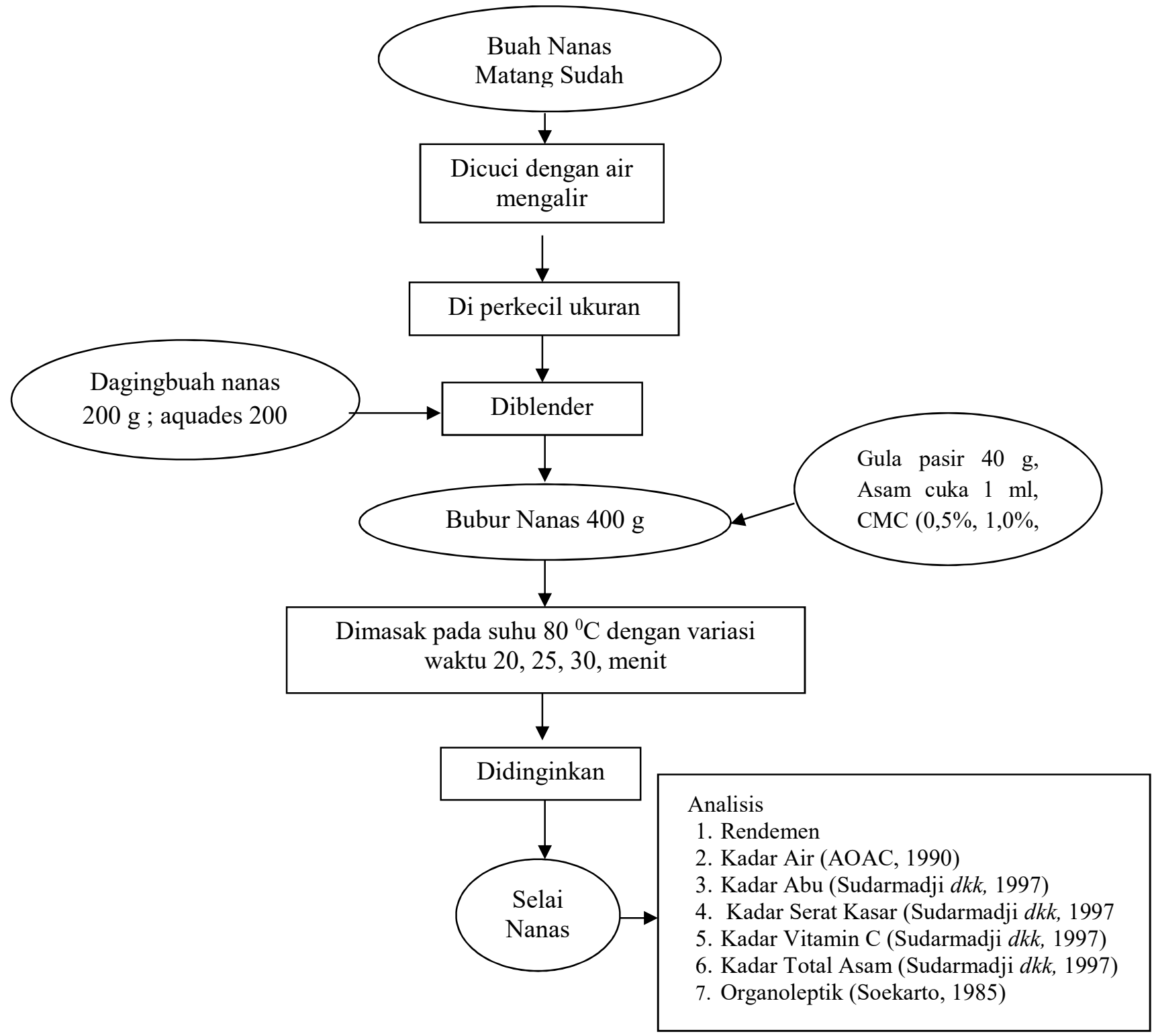

Gambar 1. Diagram Alir Pengolahan Selai Nanas 
3. Daging buah nanas dipotong menjadi potongan kecil.Kemudian daging buah nanas diblender dengan menambahkan air sebanyak $200 \mathrm{ml}$ sampai menjadi bubur nanas400 g bubur nanas dimasukkan dalam panci dengan menambahkan asam cuka $1 \mathrm{ml}$ dan CMC sesuai perlakuan $(0,5$ $\%$, 1\%, dan 1,5\%), kemudian dimasak. Selama proses pemasakan, bubur nanas diaduk terus menerus dengan

\section{HASIL DAN PEMBAHASAN}

\section{Rendemen}

Rendemen (\%) selai nanas dihitung berdasarkan berat selai nanas berat dibagi dengan buah nanas yang gunakan dikali seratus persen. Hasil analisis ragam menunjukkan bahwa kombinasi konsentrasi CMC dengan menambahkan gula sedikit demi sedikit sebanyak 40 g hingga jadi kental dan warnanya berubah menjadi cokelat, waktu pemasakanditentukan sesuai perlakuan (20, 25 dan 30 menit). Bila adonan nanas sudah kental, panci diangkat dan didinginkan.

4. Selai nanas siap untuk dianalisis di laboratorium dan uji organoleptik oleh panelis.

waktu pemasakan berpengaruh tidak nyata terhadap rendemen selai nanas. Begitu pula faktor tunggal waktu pemasakan, namun faktor tunggal konsentrasi CMC berpengaruh sangat nyata terhadap rendemen selai nanas, seperti disajikan pada Tabel 1.

Tabel 1. Rendemen selai nanas pada berbagai konsentrasi CMC dan waktu pemasakan

\begin{tabular}{|c|c|c|c|c|c|c|}
\hline \multirow{2}{*}{\multicolumn{2}{|c|}{ Perlakuan }} & \multicolumn{3}{|c|}{ Waktu Pemasakan (T) } & \multirow{2}{*}{ Rata-rata } & \multirow{2}{*}{ BNJ $\alpha=0,05$} \\
\hline & & 20 & 25 & 30 & & \\
\hline \multirow{3}{*}{$\begin{array}{l}\text { Konsentrasi } \\
\text { CMC (\%) }\end{array}$} & 0,5 & 3,35 & 3,38 & 3,69 & $3,47 \mathrm{c}$ & \multirow{3}{*}{0,92} \\
\hline & 1,0 & 4,50 & 5,47 & 5,72 & $5,23 \mathrm{~b}$ & \\
\hline & 1,5 & 7,13 & 6,84 & 6,73 & $6,90 \mathrm{a}$ & \\
\hline \multirow{2}{*}{\multicolumn{2}{|c|}{$\begin{array}{c}\text { Rata-rata } \\
\text { BNJ } \alpha=0,05\end{array}$}} & 4,99 & 5,23 & 5,38 & \multirow{2}{*}{\multicolumn{2}{|c|}{1,76}} \\
\hline & & & 0,92 & & & \\
\hline
\end{tabular}

Keterangan : angka-angka yang diikuti dengan huruf sama pada baris/kolom yang sama berbeda tidak nyata pada taraf uji BNJ $\alpha=0,05$

Tabel 1 menunjukkan bahwa konsentrasi CMC 1,5\% memberikan rata-rata rendemen selai nanas lebih tinggi $(6,90 \%)$ berbeda nyata dengan konsentrasi CMC 0,5 dan 1,0\%. CMC sebagai pengemulsi dan pengental produk selai nanas dapat mengikat air sehingga semakin tinggi konsentrasi yang digunakan maka semakin besar pula kemampuan gel selai nanas untuk mengikat air sehingga secara linear dapat meningkatkan rendemen produk.

\section{Kadar Air}

Kadar air (\%) selai nanas diukur dengan metode pengovenan atau menguapkan kandungan air bahan, selajutnya dilakukan perbandingan antara berat awal selai dikurang berat akhir setelah dioven dengan berat awal selai dikali seratus persen. Hasil analisis ragam menunjukkan bahwa kombinasi konsentrasi CMC dengan waktu pemasakan dan masingmasing faktor tunggalnya berpengaruh sangat nyata terhadap kadar air selai nanas, seperti disajikan pada Tabel 2. 
Tabel 2. Kadar air (\%) selai nanas pada berbagai konsentrasi CMC dan waktu pemasakan

\begin{tabular}{|c|c|c|c|c|c|c|}
\hline \multirow{2}{*}{\multicolumn{2}{|c|}{ Perlakuan }} & \multicolumn{3}{|c|}{ Waktu pemasakan (menit) } & \multirow{2}{*}{ Rerata } & \multirow{2}{*}{$\mathrm{BNJ} \alpha=0,05$} \\
\hline & & 20 & 25 & 30 & & \\
\hline \multirow{3}{*}{$\begin{array}{c}\text { Konsentrasi } \\
\text { CMC (\%) }\end{array}$} & 0,5 & y $46,60^{c}$ & ${ }_{x} 44,49^{a}$ & $x 43,99^{a}$ & $45,02 \mathrm{a}$ & \multirow{3}{*}{0,61} \\
\hline & 1,0 & у $59,17^{\mathrm{b}}$ & $\times 55,78^{b}$ & x $58,90^{\mathrm{b}}$ & \multirow{2}{*}{$\begin{array}{l}57,95 \mathrm{~b} \\
62,25 \mathrm{c}\end{array}$} & \\
\hline & 1,5 & ${ }_{\mathrm{x}} 61,81^{\mathrm{c}}$ & ${ }_{\mathrm{x}} 61,76^{\mathrm{c}}$ & y $63,17^{c}$ & & \\
\hline \multirow{2}{*}{\multicolumn{2}{|c|}{$\begin{array}{c}\text { Rerata } \\
\text { BNJ } \alpha=0,05\end{array}$}} & y 55,86 & x 54,01 & xy 55,35 & \multirow{2}{*}{\multicolumn{2}{|c|}{1,19}} \\
\hline & & & 0,61 & & & \\
\hline
\end{tabular}

Keterangan : angka-angka yang diikuti dengan huruf yang sama pada (kolom/baris) yang sama berbeda tidak nyata pada taraf uji BNJ $\alpha=0,05$

Tabel 2 menunjukkan bahwa kombinasi konsentrasi CMC 0,5\% dengan waktu pemasakan 30 menit memberikan rata-rata kadar air selai nanas lebih rendah $(43,99 \%)$ berbeda tidak nyata kombinasi konsentrasi CMC 0,5\% dengan waktu pemasakan 25 menit, namun berbeda nyata dengan kombinasi perlakuan lainnya. Konsentrasi CMC 0,5\% memberikan kadar air selai nanas terendah $(45,02 \%)$, berbeda nyata dengan konsentrasi CMC 1,0 dan 1,5\%. Selai merupakan semi basah berkadar air sekitar 15-40\% yang umumnya dibuat dari sari buah atau buah yang sudah dihancurkan, ditambah gula dan dimasak hingga kental atau berbentuk setengah padat (Margono $d k k, 1993$ ).

Pada semua kadar air selai nanas yang dihasilkanpada penelitian ini lebih tinggi nilainya dari kadar air selai umumnya, hal ini dimungkinkan karena gula yang digunakan pada selai umumnya lebih tinggi kadarnya dan akan memberikan air yang terkandung di dalam bahan, sehingga jumlah air bebas yang terkandung dalam bahan akan berkurang (Muchtadi, 1994). Hal ini menyebabkan kombinasi konsentrasi CMC 0,5\% dengan waktu pemasakan30 menit $(43,99 \%)$ memberikan kadar air selai nanas lebih rendah dibandingkan kombinasi lainnya.

\section{Kadar Abu}

Kadar abu (\%) selai nanas diukur dengan metode pengovenan dengan panas bertingkat hingga $500^{\circ} \mathrm{C}, \quad$ selajutnya dilakukan perbandingan antara kadar abu selai dengan berat sampel selai yang diuji dikali seratus persen. Hasil analisis ragammenunjukkan bahwa kombinasi konsentrasi CMC dengan waktu pemasakandan masing-masing faktor tunggalnya berpengaruh sangat nyata terhadap kadar abu selai nanas, seperti disajikan pada Tabel 3.

Tabel 3. Kadar abu (\%) selai nanas pada berbagai konsentrasi CMC dan waktu pemasakan

\begin{tabular}{|c|c|c|c|c|c|c|}
\hline \multirow{2}{*}{\multicolumn{2}{|c|}{ Perlakuan }} & \multicolumn{3}{|c|}{ Waktu pemasakan(menit) } & \multirow{2}{*}{ Rerata } & \multirow{2}{*}{$\mathrm{BNJ} \alpha=0,05$} \\
\hline & & 20 & 25 & 30 & & \\
\hline \multirow{3}{*}{$\begin{array}{l}\text { Konsentrasi } \\
\text { CMC (\%) }\end{array}$} & 0,5 & $x 0,86^{\mathrm{a}}$ & y $1,17^{\mathrm{b}}$ & xy $1,01^{\mathrm{ab}}$ & $1,01 \mathrm{~b}$ & \multirow{3}{*}{0,08} \\
\hline & 1,0 & $\times 0,86^{\mathrm{a}}$ & x $0,81^{\mathrm{a}}$ & $\times 0,88^{\mathrm{a}}$ & $0,85 \mathrm{a}$ & \\
\hline & 1,5 & ху $0,99^{a}$ & $\mathrm{x} 0,85^{\mathrm{a}}$ & y $1,08^{b}$ & $0,97 \mathrm{~b}$ & \\
\hline \multicolumn{2}{|c|}{ Rerata } & x 0,90 & xy 0,94 & x 0,99 & \multirow{2}{*}{\multicolumn{2}{|c|}{0,16}} \\
\hline \multicolumn{2}{|c|}{$\mathrm{BNJ} \alpha=0,05$} & \multicolumn{3}{|c|}{0,08} & & \\
\hline
\end{tabular}

Keterangan : angka-angka yang diikuti dengan huruf yang sama pada (kolom/baris) yang sama berbeda tidak nyata pada taraf uji BNJ $\alpha=0,05$ 
Tabel 3 menunjukkan bahwa kombinasi konsentrasi $\mathrm{CMC} \quad 1,0 \%$ dengan waktu pemasakan 25 menit memberikan rata-rata kadar abu selai nanas lebih rendah $(0,81 \%)$ berbeda tidak nyata dengan kombinasi perlakuan lainnya, kecuali konsentrasi CMC $0,5 \%$ dengan waktu pemasakan 25 menit dan konsentrasi CMC 1,5\% dengan waktu pemasakan 30 menit. Sebagian besar bahan makanan, yaitu sekitar 96\% terdiri dari bahan organik dan air. Sisanya terdiri dari unsurunsur mineral yang dikenal juga dengan kadar abu. Di dalam tubuh unsur mineral berfungsi sebagai zat pembangun dan pengatur. Mineral dalam selai nanas dapat terikat oleh komponen pangan lainnya atau dalam bentuk suspensi. CMC dapat membentuk sistem dispersi koloid dan meningkatkan viskositas sehingga partikel-partikel yang tersuspensi akan tertangkap (Potter and Norman, 1986).
Sedangkan waktu pemasakanyang tepat tidak merusak sistem disperse koloid yang dibentuk oleh CMC sehingga dapat menurunkan kadar abu selai nanas. Kondisi optimum tersebut terjadi pada penggunaan CMC 1,0\% dengan waktu pemasakan 25 menit.

\section{Serat kasar}

Serat kasar merupakan residu dari bahan makanan setelah diperlakukan dengan asam atau alkali mendidih, dan terdiri dari selulosa, dengan sedikit lignin dan pentosan (Sudarmadji $d k k$, 1997). Hasil analisis ragam menunjukkan bahwa kombinasi konsentrasi CMC dengan waktu pemasakanberpengaruh tidak nyata terhadap serat kasar selai nanas. Begitu pula faktor tunggal lama pemasakan, namun faktor tunggal konsentrasi CMC berpengaruh sangat nyata terhadap serat kasar selai nanas, seperti disajikan pada Tabel 4.

Tabel. 4 Serat kasar (\%) selai nanas pada berbagai konsentrasi CMC dan waktu pemasakan

\begin{tabular}{|c|c|c|c|c|c|c|}
\hline & & \multicolumn{3}{|c|}{ Waktu pemasakan $(\mathrm{T})$} & \multirow[b]{2}{*}{ Rata-rata } & \multirow[b]{2}{*}{ BNJ $\alpha=0,05$} \\
\hline \multicolumn{2}{|c|}{ Perlakuan } & 20 & 25 & 30 & & \\
\hline \multirow{3}{*}{$\begin{array}{c}\text { Konsentrasi } \\
\text { CMC (\%) }\end{array}$} & 0,5 & 1,07 & 1,07 & 1,09 & $1,08 \mathrm{a}$ & \multirow{3}{*}{0,10} \\
\hline & 1,0 & 0,92 & 0,83 & 0,85 & $0,86 \mathrm{~b}$ & \\
\hline & 1,5 & 0,74 & 0,75 & 0,74 & $0,74 \mathrm{c}$ & \\
\hline \multicolumn{2}{|c|}{ Rata-rata } & 0,91 & 0,88 & 0,89 & \multirow{2}{*}{\multicolumn{2}{|c|}{0,18}} \\
\hline \multicolumn{2}{|c|}{ BNJ $\alpha=0,05$} & & 0,10 & & & \\
\hline
\end{tabular}

Keterangan : angka-angka yang diikuti dengan huruf yang sama pada kolom yang sama berbeda tidak nyata pada taraf uji BNJ $\alpha=0,05$

Tabel 4 menunjukkan bahwa konsentrasi CMC 0,5\% memberikan rata-rata serat kasar selai nanas lebih tinggi $(1,08 \%)$ berbeda nyata dengan konsentrasi CMC $1,0 \%$ dan $1,5 \%$. Tingginya kadar serat selai nanas pada penggunaan $\mathrm{CMC} \quad 0,5 \%$ menyebabkan kompleksitas selai nanas lebih rendah sehingga bila diberikan perlakuan asam atau alkali mendidih maka sellulosa dapat terurai atau teridenfikasi secara sempurna. Kadar serat kasar dari selai nanas yang dihasilkan pada penelitian ini, lebih rendah dibandindingkan dengan standar selai nanas yaitu sebesar 3,12\% (Dewi $d k k, 2010$ ).

\section{Vitamin C}

Kadar vitamin $\mathrm{C}$ selai nanas diukur dengan metode titrasi dengan larutan Iod 0,01 N. Hasil analisis ragammenunjukkan bahwa kombinasi konsentrasi CMC dengan waktu pemasakandan masing- masing faktor tunggalnya berpengaruh sangat nyata terhadap 
kadar vitamin $\mathrm{C}$ selai nanas, seperti disajikan pada Tabel 5.

Tabel 5. Vitamin C selai nanas pada berbagai konsentrasi CMC dan waktu pemasakan

\begin{tabular}{|c|c|c|c|c|c|c|}
\hline \multirow{2}{*}{\multicolumn{2}{|c|}{ Perlakuan }} & \multicolumn{3}{|c|}{ Waktu pemasakan(menit) } & \multirow{2}{*}{ Rerata } & \multirow{2}{*}{$\mathrm{BNJ} \alpha=0,05$} \\
\hline & & 20 & 25 & 30 & & \\
\hline \multirow{3}{*}{$\begin{array}{c}\text { Konsentrasi } \\
\text { CMC (\%) }\end{array}$} & 0,5 & $\mathrm{x} 14,30^{\mathrm{a}}$ & y $12,10^{\mathrm{b}}$ & у $12,20^{\mathrm{a}}$ & $12,87 \mathrm{~b}$ & \multirow{3}{*}{0,97} \\
\hline & 1,0 & x $15,40^{\mathrm{a}}$ & ${ }_{x} 14,30^{a}$ & y $11,00^{\mathrm{a}}$ & $13,57 \mathrm{a}$ & \\
\hline & 1,5 & x $11,00^{b}$ & $\mathrm{x} 12,10^{\mathrm{b}}$ & $\times 11,00^{a}$ & $11,37 \mathrm{~b}$ & \\
\hline \multicolumn{2}{|c|}{ Rerata } & $\mathrm{x} 13,57$ & y 12,83 & z 11,40 & \multirow{2}{*}{\multicolumn{2}{|c|}{1,88}} \\
\hline \multicolumn{2}{|c|}{ BNJ $\alpha=0,05$} & \multicolumn{3}{|c|}{0,97} & & \\
\hline
\end{tabular}

Keterangan : angka-angka yang diikuti dengan huruf yang sama pada (kolom/baris) yang sama berbeda tidak nyata pada taraf uji BNJ $\alpha=0,05$

Tabel 5 menunjukkan bahwa kombinasi konsentrasi $\mathrm{CMC} \quad 1,0 \%$ dengan waktu pemasakan 20 menit memberikan rata-rata kadar vitamin C selai nanas lebih tinggi $(15,40)$ berbeda tidak nyata kombinasi konsentrasi CMC 0,5\% dengan waktu pemasakan20 menit dan konsentrasi CMC 1,0\% dengan waktu pemasakan 25 menit dan konsentrasi CMC $1,5 \%$ dengan waktu pemasakan30 menit, namun berbeda nyata dengan kombinasi perlakuan lainnya. Vitamin $\mathrm{C}$ relatif lebih stabil pada $\mathrm{pH}$ rendah dibandingkan dengan pada $\mathrm{pH}$ tinggi. Kemampuan $\mathrm{CMC}$ untuk mengikat air (Prilestari, 2001) dan waktu pemasakanakan menurunkan kadar air selai nanas akan tetapi berdampak negatif terhadap kelarutan vitamin C pada selai nanas. Karena proses pemanasan pada saat pengolahan selai nanas diduga menyebabkan penurunan kadar vitamin C.

Vitamin $\mathrm{C}$ merupakan vitamin yang paling mudah rusak, vitamin $\mathrm{C}$ mudah teroksidasi dan proses tersebut dipercepat oleh adanya panas, sinar, alkali, enzim, oksidator serta katalis lembaga dan besi (Winarno, 2008). Namun kondisi optimum agar dapat mempertahankan vitamin $\mathrm{C}$ selai nanas terjadi pada penggunaan $\mathrm{CMC} 1,0 \%$ dengan waktu pemasakan 20 menit $(15,40 \%)$.

\section{Total Asam}

Hasil analisis ragam menunjukkan bahwa kombinasi konsentrasi CMC dengan waktu pemasakandan masing-masing faktor tunggalnya berpengaruh sangat nyata terhadap total asam selai nanas, seperti disajikan pada Tabel 6 .

Tabel 6. Total asam selai nanas pada berbagai konsentrasi CMC dan waktu pemasakan

\begin{tabular}{|c|c|c|c|c|c|c|}
\hline \multirow{2}{*}{\multicolumn{2}{|c|}{ Perlakuan }} & \multicolumn{3}{|c|}{ Waktu pemasakan(menit) } & \multirow{2}{*}{ Rerata } & \multirow{2}{*}{$\mathrm{BNJ} \alpha=0,05$} \\
\hline & & 20 & 25 & 30 & & \\
\hline \multirow{3}{*}{$\begin{array}{c}\text { Konsentrasi } \\
\text { CMC (\%) }\end{array}$} & 0,5 & ${ }_{x} 21,15^{b}$ & $\mathrm{x} 21,21^{b}$ & $\mathrm{x} 19,82^{\mathrm{a}}$ & $20,73 \mathrm{~b}$ & \multirow{3}{*}{0,71} \\
\hline & 1,0 & y $20,93^{b}$ & xy $20,22^{\mathrm{ab}}$ & $\times 19,06^{\mathrm{a}}$ & $20,07 \mathrm{~b}$ & \\
\hline & 1,5 & x $17,39^{a}$ & y $19,36^{\mathrm{a}}$ & у $19,62^{a}$ & $18,79 \mathrm{a}$ & \\
\hline \multicolumn{2}{|c|}{$\begin{array}{c}\text { Rerata } \\
\text { BNJ } \alpha=0,05\end{array}$} & xy 19,82 & y 20,26 & $\mathrm{x} 19,50$ & \multicolumn{2}{|c|}{1,39} \\
\hline
\end{tabular}

Keterangan : angka-angka yang diikuti dengan huruf yang sama pada (kolom/baris) yang sama berbeda tidak nyata pada taraf uji $\mathrm{BNJ} \alpha=0,0$ 
Tabel 6 menunjukkan bahwa kombinasi konsentrasi $\mathrm{CMC} \quad 1,5 \%$ dengan waktu pemasakan 20 menit memberikan rata-rata total asam selai nanas lebih rendah $(17,39)$ berbeda tidak nyata kombinasi konsentrasi CMC 1,0\% dengan waktu pemasakan 25 menit, kombinasi konsentrasi CMC 0,5\% dan $1,0 \%$ dengan waktu pemasakan30 menit, namun berbeda nyata dengan kombinasi perlakuan lainnya. Pada penggunaan bahan penstabil pada konsentrasi yang tinggi dapat menyebabkan aktifitas bakteri asam laktat untuk mengubah laktosa menjadi asam laktat kurang optimal sehingga asam yang dihasilkan berkurang dan nilai $\mathrm{pH}$ akan tinggi (Hui, 1993 dalam Sumardikan, 2007).

Didukung dengan pendapat Ganz (1997), terlihat kecenderungan penurunan $\mathrm{pH}$ dengan semakin meningkatnya jumlah CMC yang ditambahkan. CMC merupakan hidrokoloid yang mengandung gugus karboksil (-COOH) dan mudah terhidrolisis. Gugus karboksil memberikan sifat asam. Semakin banyak jumlah CMC yang ditambahkan maka kemungkinan semakin rendah $\mathrm{pH}$ selai nanas. Sehingga penggunaan CMC 1,5\% memberikan total asam selai nanas lebih rendah yang didukung oleh waktu pemasakansingkat (20 menit) menyebabkan oksidasi gula sederhana menjadi asam lebih rendah.

\section{Warna}

Hasil analisis ragam menunjukkan bahwa kombinasi konsentrasi CMC dengan waktu pemasakandan faktor tunggal konsentrasi $\mathrm{CMC}$ berpengaruh sangat nyata terhadap warna selai nanas, seperti disajikan pada Tabel 7.

Tabel 7. Penilaian panelis terhadap warna selai nanas pada berbagai konsentrasi CMC dan waktu pemasakan

\begin{tabular}{|c|c|c|c|c|c|c|}
\hline \multirow{2}{*}{\multicolumn{2}{|c|}{ Perlakuan }} & \multicolumn{3}{|c|}{ Waktu pemasakan(menit) } & \multirow{2}{*}{ Rata-rata } & \multirow{2}{*}{$\mathrm{BNJ} \alpha=0,05$} \\
\hline & & 20 & 25 & 30 & & \\
\hline \multirow{3}{*}{$\begin{array}{c}\text { Konsentrasi } \\
\text { CMC (\%) }\end{array}$} & 0,5 & $x 4,40^{a}$ & $\times 4,28^{a}$ & xy $4,08^{a}$ & $4,25 \mathrm{a}$ & \multirow{3}{*}{0,34} \\
\hline & 1,0 & y $3,80^{a}$ & $\times 3,92^{a}$ & $\mathrm{x} 3,84^{\mathrm{b}}$ & $3,85 \mathrm{~b}$ & \\
\hline & 1,5 & ${ }_{x} 4,08^{a}$ & y $3,04^{\mathrm{b}}$ & $\mathrm{x} 3,88^{\mathrm{a}}$ & $3,67 \mathrm{~b}$ & \\
\hline
\end{tabular}

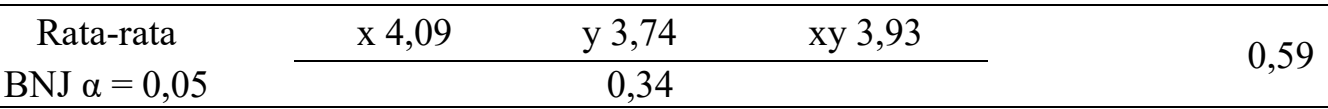

Keterangan : angka-angka yang diikuti dengan huruf yang sama pada (kolom/baris) yang sama berbeda tidak nyata pada taraf uji BNJ $\alpha=0,05$

Tabel 7 menunjukkan bahwa produk selai nanas dari kombinasi konsentrasi CMC $0,5 \%$ dengan waktu pemasakan 20 menit dinilai oleh panelis dengan skor penilaian warna tertinggi $(4,40$ atau skala hedonik "suka") berbeda tidak nyata dengan kombinasi lainnya, kecuali kombinasi CMC 1,0\% dengan waktu pemasakan 20 menit dan CMC 1,5\% dengan waktu pemasakan 25 menit. Selai nanas dengan konsentrasi CMC 0,5\%, dinilai oleh panelis dengan skor penilaian warna tertinggi (4,25 atau skala hedonik "suka") berbeda nyata dengan konsentrasi CMC lainya. Selai nanas dengan waktu pemasakan 20 menit, dinilai oleh panelis dengan skor penilaian warna tertinggi $(4,09$ atau skala hedonik "suka") berbeda tidak nyata dengan waktu pemasakan 25 menit, namun berbeda nyata dengan waktu pemasakan 30 menit.

Warna selai nanas kombinasi penggunaan $\mathrm{CMC} \quad 0,5 \%$ dengan waktu pemasakan 20 menit dinilai oleh panelis dengan warna terbaik dalam penelitian ini disebabkan karena penyimpangan warna produk selai 
nanas sangat kecil dari pigmen warna kuning cerah daging buah nanas. Peningkatan konsentrasi CMC dapat meningkatkan kompleksitas selai nanas sehingga menjadi peka terhadap suhu dan lama pemanasan. Menurut Pratiwi (2009) bahwa pencoklatan non enzimatis dapat terjadi bahan pangan dengan kadar gula tinggi akibat reaksi maillard dan karamelisasi.

\section{Aroma}

Hasil analisis ragam menunjukkan bahwa kombinasi konsentarsi CMC dan waktu pemasakanserta faktor tunggal masing-masing berpengaruh sangat nyata terhadap skor penilaian aroma selai nanas oleh panelis.

Tabel 8 menunjukkan bahwa kombinasi penggunaan $\mathrm{CMC} \quad 0,5 \%$ dengan waktu pemasakan 20 menit diperoleh skor penilaian aroma selai nanas tertinggi $(4,72)$ atau (skala hedonik "sangat suka") berbeda tidak nyata dengan kombinasi penggunaan CMC 1,5\% dengan waktu pemasakan 25 dan 30 menit, kombinasi penggunaan $\mathrm{CMC} 1,0 \%$ dengan waktu pemasakan 30 menit, namunberbeda nyata dengan kombinasi penggunaan $\mathrm{CMC}$ dan waktu pemasakan lainnya.

Tabel 8. Skor penilaian panelis terhadap aroma selai nanas pada berbagai konsentrasi CMC dan waktu pemasakan

\begin{tabular}{|c|c|c|c|c|c|c|}
\hline \multirow{2}{*}{\multicolumn{2}{|c|}{ Perlakuan }} & \multicolumn{3}{|c|}{ Waktu pemasakan(menit) } & \multirow{2}{*}{ Rata-rata } & \multirow{2}{*}{$\mathrm{BNJ}$} \\
\hline & & 20 & 25 & 30 & & \\
\hline \multirow{3}{*}{$\begin{array}{l}\text { Konsentrasi } \\
\text { CMC (\%) }\end{array}$} & 0,5 & ${ }_{x} 4,72^{a}$ & xy $3,48^{b}$ & $\times 3,88^{b}$ & $4,03 \mathrm{a}$ & \multirow{3}{*}{0,31} \\
\hline & 1,0 & y 3,64 a & y $3,32^{a}$ & $\mathrm{x} 3,88^{\mathrm{a}}$ & $3,61 \mathrm{~b}$ & \\
\hline & 1,5 & у $3,76^{\mathrm{a}}$ & $\times 4,00^{\mathrm{a}}$ & ${ }_{x} 4,00^{a}$ & $3,92 \mathrm{ab}$ & \\
\hline \multicolumn{2}{|c|}{ Rata-rata } & $\mathrm{x} 4,04$ & z 3,60 & xy 3,92 & & \multirow{2}{*}{0,53} \\
\hline \multicolumn{2}{|l|}{ BNJ } & \multicolumn{3}{|c|}{0,31} & & \\
\hline
\end{tabular}

$\overline{\text { Keterangan : angka-angka yang diikuti dengan huruf yang sama pada (kolom/baris) yang sama berbeda tidak }}$ nyata pada taraf uji BNJ $\alpha=0,05$

Aroma selai nanas yang diproduksi pada penelitian ini adalah aroma asam. Aroma tersebut timbul karena penguraian gula menjadi asam laktat dan asetaldehid. Menurut Walstra dkk (1999), penambahan bahan penstabil dengan persentase yang besar dapat menghambat proses metabolisme bakteri asam laktat dalam menghasilkan asam laktat, asetaldehida, diasetil dan senyawa lainnya yang berperan pada aroma. Hal inilah yang menyebabkan panelis memberikan penilaian aroma selai nanas tertinggi pada penggunaan CMC $0,5 \%$ dan pada waktu pemasakan 20 menit diduga disebabkan karena pemasakan yang kurang lama sehingga mengakibatkan terjadinya gula yang teroksidasi.

\section{Rasa}

Hasil analisis ragam menunjukkan bahwa kombinasi konsentrasi CMC dengan waktu pemasakandan faktor tunggal waktu pemasakanberpengaruh tidak nyata terhadap skor penilaian rasa selai nanas oleh panelis. Sedangkan faktor tunggal konsentrasi CMC berpengaruh sangat nyata terhadap penilaian rasa selai nanas oleh panelis. 
Tabel 9. Skor penilaian panelis terhadap rasa selai nanas pada berbagai konsentrasi CMC dan waktu pemasakan

\begin{tabular}{|c|c|c|c|c|c|c|}
\hline \multirow{2}{*}{\multicolumn{2}{|c|}{ Perlakuan }} & \multicolumn{3}{|c|}{ Waktu pemasakan(menit) } & \multirow{2}{*}{ Rata-rata } & \multirow{2}{*}{$\mathrm{BNJ} \alpha=0,05$} \\
\hline & & 20 & 25 & 30 & & \\
\hline \multirow{3}{*}{$\begin{array}{c}\text { Konsentrasi } \\
\text { CMC (\%) }\end{array}$} & 0,5 & 4,56 & 4,24 & 4,20 & $4,33 \mathrm{a}$ & \multirow{3}{*}{0,30} \\
\hline & 1,0 & 3,76 & 3,72 & 3,92 & $3,80 \mathrm{~b}$ & \\
\hline & 1,5 & 3,92 & 3,80 & 3,92 & $3,88 \mathrm{~b}$ & \\
\hline \multicolumn{2}{|c|}{ Rata-rata } & 4,08 & 3,92 & 4,01 & \multirow{2}{*}{\multicolumn{2}{|c|}{0,52}} \\
\hline \multicolumn{2}{|c|}{$\mathrm{BNJ} \alpha=0,05$} & & 0,30 & & & \\
\hline
\end{tabular}

Keterangan : angka-angka yang diikuti dengan huruf yang sama pada (kolom/baris) yang sama berbeda tidak nyata pada taraf uji $\mathrm{BNJ} \alpha=0,05$

Tabel 9 menunjukkan bahwa selai nanas dengan konsentrasi CMC 0,5\% dinilai oleh panelis dengan penilaian rasa tertinggi $(4,33$ atau skala hedonik "suka"), berbeda nyata dengan konsentrasi CMC 1,0 dan 1,5\%. Selai nanas memiliki dua rasa dasar, yaitu rasa manis dari kandungan gula dan rasa asam akibat hidrolisis senyawa gula. Penambahan gula dalam pembuatan selai nanasbertujuan untuk memperoleh tekstur dan flavour yang ideal. Oleh sebab itu penambahan gula yang tepat dipengaruhi oleh beberapa faktor yaitu keasaman buah, kandungan gula dan tingkat kematangah buah. Gula dapat berpengaruh terhadap keseimbangan air dan pektin yang ada, oleh sebab itu pada nanas dengan kandungan pektin rendah, penambahan gula lebih sedikit dari bagian buahnya (Linda, 2005).Sehingga dengan penggunaan CMC $0,5 \%$ lebih besar penerimaan oleh panelis, namun berbeda dgn konsentrasi CMC lainnyamenyebabkan penerimaan panelis berkurang.

\section{Tekstur}

Hasil analisis ragam menunjukkan bahwa kombinasi konsentarsi CMC dengan waktu pemasakan dan faktor tunggal waktu pemasakan berpengaruh tidak nyata, Sedangkan faktor tunggal konsentrasi CMC berpengaruh sangat nyata terhadap penilaian tekstur selai nanas oleh panelis.

Tabel 10. Skor penilaian panelis terhadap tekstur selai nanas pada berbagai konsentrasi CMC

\begin{tabular}{|c|c|c|c|c|c|c|}
\hline \multirow{2}{*}{\multicolumn{2}{|c|}{ Perlakuan }} & \multicolumn{3}{|c|}{ Waktu pemasakan(menit) } & \multirow{2}{*}{ Rata-rata } & \multirow{2}{*}{ BNJ $\alpha=0,05$} \\
\hline & & 20 & 25 & 30 & & \\
\hline \multirow{3}{*}{$\begin{array}{c}\text { Konsentrasi } \\
\text { CMC (\%) }\end{array}$} & 0,5 & 4,40 & 4,00 & 4,20 & $4,20 \mathrm{a}$ & \multirow{3}{*}{0,32} \\
\hline & 1,0 & 4,04 & 3,72 & 3,88 & $3,88 \mathrm{~b}$ & \\
\hline & 1,5 & 3,76 & 4,08 & 4,00 & $3,95 \mathrm{ab}$ & \\
\hline \multicolumn{2}{|c|}{ Rata-rata } & 4,07 & 3,93 & 4,03 & \multirow{2}{*}{\multicolumn{2}{|c|}{0,54}} \\
\hline \multicolumn{2}{|c|}{$\mathrm{BNJ} \alpha=0,05$} & & 0,32 & & & \\
\hline
\end{tabular}

Keterangan : angka-angka yang diikuti dengan huruf yang sama pada (kolom/baris) yang sama berbeda tidak nyata pada taraf uji BNJ $\alpha=0,05$

Tabel 10 menunjukkan bahwa selai nanas dengan konsentrasi $\mathrm{CMC} 0,5 \%$ dinilai oleh panelis dengan penilaian tekstur tertinggi
(4,20 atau skala hedonik “suka”), berbeda tidak nyata dengan konsentrasi $1,5 \%$, namun berbeda nyata dengan konsentrasi CMC 1,0\%. 
Untuk untuk mendapatkan tekstur selai yang baik dengan viskositas tetap diperlukan pektin, gula, dan asam dalam jumlah yang tepat. Gel yang terbentuk dari pektin dan gula memberikan tektur yang kuat (Ginting $d k k$, 2007). Dan selai dibuat dengan konsentrasi pada campuran menggunakan perlakuan panas pada tekanan normal atau kurang, yang menghasilkan konsistensi kental atau gel. Hal ini menjain kerusakan enzim buah, pektin dari buahdan konsentrat produknya pada titik dimana keasaman dan aktivitas air mengurangi daya tahannya (Fasogbon $d k k, 2013$ ) dan perubahan tekstur dan menjatuhkan sedikit sampel diatas piring untuk melihat sampel selai dapat terjatuh atau tidak (Eke-Ejofor, 2013). Sehingga dengan konsentrasi CMC 0,5\% dengan waktu pemasakan 20 menit $(4,20)$ lebih besar mendapatkan penerimaan oleh panelis dibandingkan yang lainnya.

\section{Kesukaan keseluruhan}

Hasil sidik ragam menunjukkan bahwa kombinasi konsentarsi CMC dan waktu pemasakanberpengaruh sangat nyata terhadap derajat kesukaan panelis terhadap produk selai nanas. Adapun faktor tunggal konsentrasi CMC dan waktu pemasakan berpengaruh tidak nyata terhadap derajat kesukaan panelis terhadap selai nanas.

Tabel 11 menunjukkan bahwa selai nanas dari kombinasi konsentrasi CMC 0,5\% dengan waktu pemasakan 20 menit, dinilai oleh panelis dengan rata-rata derajat kesukaan tertinggi (4,60 atau skala hedonik "sangat suka") berbeda tidak nyata dengan kombinasi konsentrasi CMC dengan waktu pemasakanlainnya, kecuali kombinasi konsentrasi CMC 1,0\% dengan waktu pemasakan 20 menit.

Tabel 11. Derajat kesukaan panelis terhadap selai nanas pada berbagai konsentrasi CMC dan lama pemasakan

\begin{tabular}{|c|c|c|c|c|c|c|}
\hline \multirow{2}{*}{\multicolumn{2}{|c|}{ Perlakuan }} & \multicolumn{3}{|c|}{ Waktu pemasakan(menit) } & \multirow{2}{*}{ Rata-rata } & \multirow{2}{*}{$\mathrm{BNJ} \alpha=0,05$} \\
\hline & & 20 & 25 & 30 & & \\
\hline \multirow{3}{*}{$\begin{array}{c}\text { Konsentrasi } \\
\text { CMC (\%) }\end{array}$} & 0,5 & ${ }_{x} 4,60^{\mathrm{a}}$ & $\times 4,40^{\mathrm{a}}$ & $\times 4,12^{\mathrm{a}}$ & 4,37 & \multirow{3}{*}{0,30} \\
\hline & 1,0 & у $3,96^{\mathrm{b}}$ & $x y 4,16^{a}$ & $\mathrm{x} 4,52^{\mathrm{a}}$ & 4,21 & \\
\hline & 1,5 & ${ }_{x} 4,28^{a}$ & $\times 4,36^{\mathrm{a}}$ & $\times 4,08^{a}$ & 4,24 & \\
\hline \multirow{2}{*}{\multicolumn{2}{|c|}{$\mathrm{BNJ} \alpha=0,05$}} & 4,28 & 4,31 & 4,24 & \multirow{2}{*}{\multicolumn{2}{|c|}{0,51}} \\
\hline & & & 0,30 & & & \\
\hline
\end{tabular}

Keterangan : angka-angka yang diikuti dengan huruf yang sama pada (kolom/baris) yang sama berbeda tidak nyata pada taraf uji BNJ $\alpha=0,05$

Secara umum panelis menilai produk selai nanas dalam penelitian ini dengan derajat kesukaan (suka dan sangat suka). Artinya panelis menerima semua produk selai nanas dengan baik. Untuk menghasilkan selai nanas yang berkualitas baik, buah yang dipilh harus matang optimal, karena pada kondisini ini buah nanas memiliki aroma kuat, sehingga hasil olahannya membuat aroma yang kuat, karena buah yang matang penuh akan memberikan aroma yang kuat (Satuhu, 1994; Fachrudin,
1997) dan penambahan gula yang tepat dan waktu yang tidak terlalu lama memberikan kualitasnanas yang dihasilkan baik, sehingga pada selai nanas dengan kombinasi konsentrasi CMC 0,5\% dengan waktu pemasakan 20 menit memberikan penilaian panelis dengan derajat kesukaan tertinggi. 


\section{KESIMPULAN}

1. Kombinasi terbaik terdapat pada perlakuan konsentrasi CMC 0,5\% dengan waktu pemasakan 20 menit.

2. Karakteristik perlakuan konsentrasi $\mathrm{CMC}$ $0,5 \%$ dengan waktu pemasakan 20 menit menghasilkan selai nanas lebih baik antara lain kadar air(46,60\%), kadar abu $(0,86 \%)$, kadar vitamin C $(14,30 \%)$, dan organoleptik terbaik terhadap aroma selai nanas pada perlakuan konsentrasi CMC $0,5 \%$ dengan waktu pemasakan 20 menit diperoleh skor penilaian panelis tertinggi sebesar $(4,72)$ dengan skala hedonik "sangat suka".

\section{DAFTAR PUSTAKA}

AOAC. 1990. Official Methods of Analisis. Association of Official Analitycal, Penerbit UGM, Yogyakarta.

Balai Pengkajian Teknologi Pertanian. 2007. Budidaya dan Pasca Panen Nanas. Badan Penelitian dan Pengembangan Pertanian Departemen Pertanian. Kalimantan Timur.

Dewi, Eko, N Titi Surti dan Ulfatun. 2010. Kualitas Selai yang Diolah dari Rumput Laut, Gracilaria verrucosa, Eucheuma cottonii, serta Campuran Keduanya. Universitas Diponegoro. Semarang.

Eke-Ejiofor J. And Owuno F. 2013. The Physico-Chemical and Sensory Properties of Jackfruit (Artocarpus heterophilus) Jam. International Journal of Nutrition and Food Sciences. 2 (3) : $149-152,2013$.

Fachrudin, L. 1997. Membuat Aneka Selai. Teknologi Tepat Guna. Kanisius. Yogyakarta.
Fasogbon, Beatrice M., Saka O. Gbadamosi, and Kehinde A. Taiwo. 2013. Studies on the Chemical and Sensory Properties of Jam from Osmotically Dehydrated Pineapple Slices. British Journal of Applied Science and Technology 3 (4) : 1327 - 1335, 2013.

Ginting, Erliana, Nila Prasetiaswati, dan Yudi Widodo. 2007. Peningkatan Daya Guna dan Nilai Tambah Ubi Jalar Berukuran Kecil melalui Pengolahan Menjadi Saos dan Selai. Journal Iptek Tanaman Pangan vol. 2, No. 1, 2007.

Indriyani S. 2008. Panduan PengembanganIndustri Buah Nanas di Industri Kecil. http://sriindri.tripod.com [02 Januari 2018].

Margono, T., D, Suryati \& S. Harinah. 1993. Buku Panduan Teknologi Pangan. Kantor Deputi Menegristik Bidang Pendayagunaan dan Pemasyarakatan Iptek.

Muchtadi, D. 1994. Fisiologi Pasca Panen Sayuran dan Buah-Buahan. Pusat Antar Universitas Pangan dan Gizi, IPB. Bogor.

Posman S., 2008. Sari Buah Nanas Kaya Manfaat: Alternatif Meningkatkan Nilai Ekonomis Hasil Panen. Sinar Tani. Medan

Potter W. and Norman, N. 1986. Food Science. The AVI Publishing Co, Inc. Westport. Connecticut

Pratiwi, 2009. Formulasi, Uji Kecukupan Panas, Dan Pendugaan Umur Simpan Minuman Sari Wornas (Wortel-Nanas). [Skripsi]. Fakultas Teknologi Pertanian Institut Pertanian Bogor, Bogor 
Prilestari, C.D. 2001. Pengaruh Penambahan CMC Sebagai Bahan Penstabil Emulsi Terhadap pH, Keasaman, Overrun, Kecepatan Meleleh Dan Mutu Organoleptik Yogurt Beku. [Skripsi]. Teknologi Hasil Ternak. Fakultas Peternakan. Universitas Brawijaya. Malang

Satuhu, S. 1994. Penanganan dan Pengolahan Buah. Penebar Swadaya. Jakarta.

Soekarto.1985. Penelitian Organoleptik untuk Industri Pangandan Hasil Pertanian. BharataAksara. Jakarta. 144 p.

Sudarmadji, S., Bambang H. dan Suhardi. 1997. Prosedur Analisa Untuk Bahan Makanan dan Pertanian. Liberty. Yogyakarta. 29-97 p.
Sumardikan, H., 2007. Penggunaan carboxy methyl cellulose $(\mathrm{cmc})$ terhadap $\mathrm{pH}$, keasaman, viskositas, sineresis dan Mutu Organoleptik Yogurt Set. [Skripsi]. Program Studi Teknologi Hasil Ternak Fakultas Peternakan Universitas Brawijaya, Malang

Syahrumsyah H., W. Murdianto, N. Pramanti, 2010. Pengaruh Penambahan Karboksi Metil Selulosa (CMC) dan Tingkat Kematangan Buah Nanas (Anana comosus (L) Merr.) Terhadap Mutu Selai Nanas. Universitas Mulawarman. Samarinda. Jurnal Teknologi Pertanian 6 (1) : 34-40, 2010.

Walstra, P., Geurts, T.J., Noomen, A., Jellema, A. and Van Boekel, M.A.J.S. 1999. The Dairy of Technology. Mc Graw Hill Publishing. New York

Winarno, F.G. 2008. Kimia Pangan dan Gizi. M-Brio Press. Bogor 